\title{
Correlation of Eemian sections in Lithuania and Belarus based on palaeomagnetic, radioisotope and palaeobotanic data
}

\author{
Vaida ŠEIRIENE' ${ }^{1, ~ *, ~ A l e x a n d e r ~ K A R A B A N O V ~} 2$, Valentinas BALTRŨNAS ${ }^{1}$, Bronislavas KARMAZA ${ }^{1}$, \\ Valentas KATINAS ${ }^{1}$, Violeta PUKELYTE் ${ }^{1}$, Tatyana RYLOVA ${ }^{2}$ and Svetlana DEMIDOVA ${ }^{2}$ \\ 1 Nature Research Centre, Institute of Geology and Geography, Akademijos 2, 08412 Vilnius, Lithuania \\ 2 National Academy of Sciences of Belarus, Institute for Nature Management, Skoriny 10, 220114 Minsk, Belarus
}

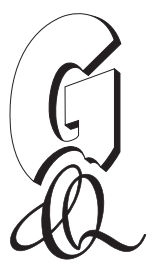

\begin{abstract}
Šeirienè, V., Karabanov, A., Baltrūnas, V., Karmaza, B., Katinas, V., Pukelytè, V., Rylova, T., Demidova, S., 2021. Correlation of Eemian sections in Lithuania and Belarus based on palaeomagnetic, radioisotope and palaeobotanic data. Geological Quarterly, 65: 46, doi: 10.7306/gq.1615
\end{abstract}

Associate Editor: Wojciech Granoszewski

Eemian (Murava, Merkinè) deposits at five exposed sections (Zaslavl, Zhukevichi, Ponemun, Snaigupèlè, and Netiesos) located in Lithuania and Belarus are described. Preliminary palaeomagnetic results show a record of the Brunhes epoch normal magnetic field and a short-term reversal - the Blake Event - is recognized in three of the five sections. The Blake Event recorded in the Netiesos section is characterized by a pattern consisting of three short reversed polarity intervals separated by two short normal polarity intervals. The directional changes of declination, inclination, and MS (magnetic susceptibility) are clear. ESR dating $(112.5 \pm 10.8$ and $112.1 \pm 25.9)$ and ${ }^{230} \mathrm{Th} / \mathrm{U}$ dates obtained from this section $(108.8 \pm 12.0 / 9.9$ ka for the L/L technique and 100.2 $\pm 10.3 / 8.6 \mathrm{ka}$ for the TSD technique) suggest that (Blake and post-Blake) palaeomagnetic excursions are present in this section. Palaeobotanical analysis and isotope dating of the Netiesos section suggest that the Blake Event occurred during the climatic optimum.

Key words: Eemian Interglacial, Blake Event, radioisotopes, pollen, Belarus, Lithuania.

\section{INTRODUCTION}

The Quaternary geology of Lithuania and Belarus is similar, as the areas of both neighbouring countries belong to the zone of continental glaciations and the thickness of the Quaternary cover varies from 10 up to $300 \mathrm{~m}$ (Guobyte and Satkūnas, 2011; Karabanov and Matveev, 2011). The stratigraphy and correlation of sedimentary layers and sections have been among the most important and controversial research subjects in Lithuania and Belarus for many years. The Quaternary stratigraphic subdivision developed in the mid-1990s was mainly based on lithostratigraphy (petrography and mineralogy) and biostratigraphy (pollen, macroplant remains, diatoms, mammals and molluscs) data (Lindner and Sanko, 2008; Šeirienè et al., 2015). Some palaeomagnetic studies were also performed, but no broader stratigraphic generalizations were made (e.g., Pevzner and Gaigalas, 1976; Sanko and Moiseev, 1996; Sanko et al., 2004; Baltrūnas et al., 2013, 2015; Bitinas et al., 2014, 2015). During the last few decades, there have been few new

\footnotetext{
* Corresponding author, e-mail: vaida.seiriene@gamtc.lt
}

Received: April 14, 2021; accepted: August 24, 2021; first published online: September 14, 2021 boreholes and there is little hope of finding new sections which could alter or supplement the existing stratigraphic charts. Consequently, much attention was paid to the application of new methods and methodological approaches, and the improvement of dating.

Important issues include the age and duration of the last interglacial period, as well as palaeomagnetic investigations, which are still few in this region. Investigations of the Earth's geomagnetic field reversals and excursions plays an important role in Quaternary stratigraphy: in correlating sections and understanding aspects of the global climate and surface processes. Identification of the reversal boundaries can be used to provide accurate time planes for geologic correlations. The pattern of such reversals during the past five million years has been well established. However, many questions regarding the duration, structure, and timing of the reversals remain problematic.

This study correlates palaeo-events/sections within the region, using the results of palaeomagnetic, palaeobotanical, and radioisotope studies to establish their relationship to contemporaneous global environmental changes. Five sections representing the last interglacial of the Late Pleistocene located in western and central Belarus and southern Lithuania were studied. The results extend our understanding of palaeoenvironmental changes in the region during the Late Pleistocene Eemian Interglacial (Murava Interglacial in Belarus and Merkiné Interglacial in Lithuania) and help establish their wider relationships. 

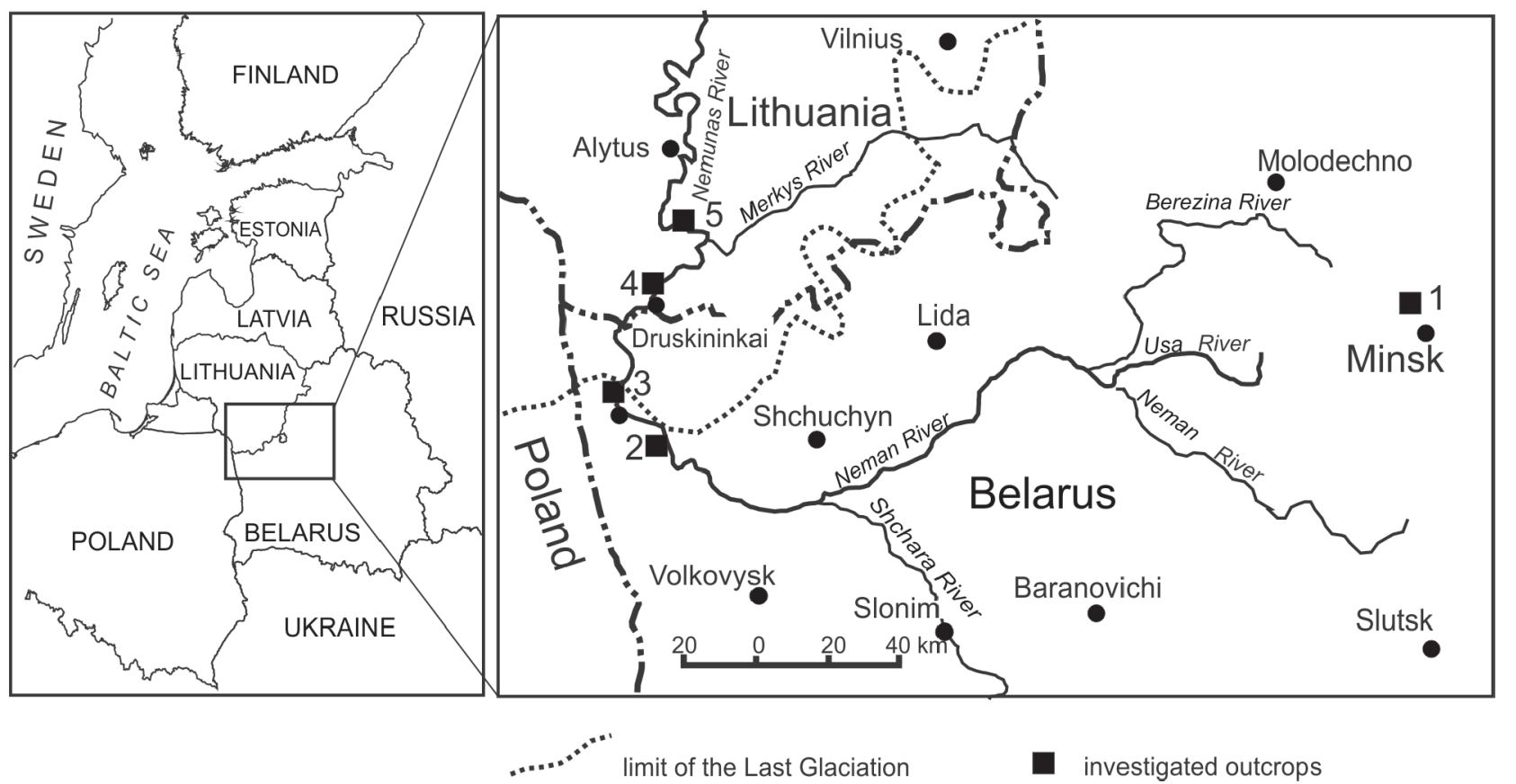

Fig. 1. Study area in Lithuania and Belarus and location of the sections investigated

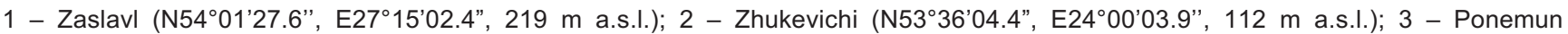

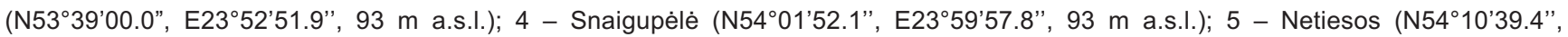
E24 $03^{\prime} 04.4^{\prime \prime}, 88.2 \mathrm{~m}$ a.s.I.); the coordinates (WGS 84 coordination system) and altitudes (approximate position of the tops of sections investigated, in metres above mean sea level) are given

\section{REGIONAL SETTING}

The sites investigated occur as exposures of generally similar lithologies. The main difference is that the sections in southern Lithuania are situated inside the area of the Last Glaciation and associated with subsequent processes of erosion and sedimentation, while the sections in Belarus occur outside the limit of the Last Glaciation (Fig. 1).

The Zaslavl, Zhukevichi and Ponemun sections are in Belarus, extending south and southeast outside the limit of the Last Glaciation. The Zaslavl section is in the kame-sandur landscape of the Minsk Elevation formed during the Oshmyany phase of the Dnieper (Pripyat) Glacial. The Zhukevichi and Ponemun sections are within the Neman (Nemunas) River valley on the highest erosional terrace. The geomorphological environment and geological setting of all these sections have been closely studied, with palaeobotanical data described in many papers (e.g., Karabanov and Elovicheva, 1997; Sanko et al., 2002; Lindner and Sanko, 2008; Karabanov et al., 2017). Here we provide a preliminary study of palaeomagnetic data.

The Snaigupèle and Netiesos sections are located in the Nemunas River valley, Lithuania, within the second and fourth raised terraces above the floodplain extending to the north of the limit of the Last Glaciation. They are well studied, and geological, palaeobotanical, geochemical, palaeomagnetic and geochronological data has already been published (Baltrūnas et al., 2013, 2015). Here we provide new palaeomagnetic and geochronological results from the Netiesos section with reference to the Blake Event.

\section{METHODS}

Palaeomagnetic investigations. The palaeomagnetic data described in this paper include determination of the aniso- tropy of magnetic susceptibility (AMS) and investigations of remanent magnetisation. The palaeomagnetic measurements were performed at the Palaeomagnetic Laboratory of the Institute of Geology and Geography, Nature Research Centre, Lithuania, using equipment manufactured by AGICO (Czech Republic) and MOLSPIN Ltd. (United Kingdom). The samples for palaeomagnetic research were collected from all the sections: 23 samples from Zaslavl, 44 from Zhukevichi, 44 from Ponemun, and 73 from Netiesos. Sampling was undertaken through the whole vertical thickness of each section at $2-10 \mathrm{~cm}$ intervals. Samples were taken by pressing sediments into special plastic containers (Natsuhara Giken Co.).

The anisotropy of magnetic susceptibility (AMS) was measured along fifteen different directions (Jelinek, 1977) with a MFK1-B kappabridge (AGICO). The analysis of the AMS data was performed using Anisoft 4.2 software.

After the AMS analysis, samples with the same orientation were used for the remanent magnetisation studies. The natural remanent magnetisation (NRM) of samples was measured using a JR-6 spinner magnetometer (AGICO). Magnetic declination and magnetic inclination were then determined and plotted for each sample. All the samples were subjected to stepwise alternating field (AF) demonetarisation with an AF demagnetizer (MOLSPIN Ltd.). The results of the demagnetisation were obtained and shown as stereographic projections, Irm/Inrm, x, y and $z$ projections. The characteristic directions were calculated using principal component analysis (Kirschvink, 1980). The analysis of the NRM was performed using Remasoft 30 software.

Magnetic susceptibility (MS) measurements. Mass magnetic susceptibility $\left(\mathrm{m}^{3} / \mathrm{kg}\right)$ was measured using a kappabridge MFK-1B (AGICO). The analysis of the anisotropy of magnetic susceptibility (AMS) was applied to allow reconstruction of sediment inflow into the basin and its transport. An AMS measurement of one sediment specimen results in an ellipsoid of magnetic susceptibility $(\mathrm{K})$ defined by the length and 
orientation of its three principal axes, $\mathrm{K}_{\max }>\mathrm{K}_{\text {int }}>\mathrm{K}_{\min }$, which are the eigenvectors of the susceptibility tensor (Tarling and Hrouda, 1993; Jezek and Hrouda, 2004). The long axis of the magnetic susceptibility ellipsoid $\mathrm{K}_{\max }$ defines the magnetic lineation; $\mathrm{K}_{\min }$ (short axis) defines the magnetic foliation. According to an expected model, the magnetic lineation should coincide with the sedimentary flow directions, while $\mathrm{K}_{\text {min }}$ is perpendicular $\left(90^{\circ}\right)$ to the direction of the flow (Cañón-Tapia, 2004). Many studies have shown that magnetic fabric provides a reliable strain indicator (cf. Graham, 1966; Henry, 1973; Hrouda and Janak, 1976; Hrouda et al., 1978; Hrouda, 1979, 2002; Ferre et al., 2004).

The ${ }^{230} \mathrm{Th} / \mathrm{U}$ dating technique. These investigations were carried out in the laboratory of St. Petersburg State University. For ${ }^{230} \mathrm{Th} / \mathrm{U}$ dating of the buried organic-rich deposits of the Netiesos section using a new version of isochron approach, the following was done (Maksimov and Kuznetsov, 2010; Kuznetsov and Maksimov, 2012; Baltrūnas et al., 2015): (1) radiochemical analysis of isotopes of $U$ and $T h$ in the same samples via leaching (L/L-technique) and total sample dissolution (TSD-technique); (2) comparison of the experimental isotopic data and identification of samples belonging to closed geochemical systems; (3) isochronous correction dating individually by each of the techniques (L/L and TSD) for different combinations of samples; and (4) determination of the final isochronous age based on the greatest similarity of isochron-calibrated dates in the same combination of samples treated using the L/L and TSD techniques. The radiochemical analysis of organic-rich deposits includes the 5 steps described by Kuznetsov and Maksimov (2012).

\section{RESULTS}

Zaslavl section. The Zaslavl section AMS measurements suggest two directions of flow of sedimentary material: direction I (A) with a declination of $273^{\circ}$ and inclination of $15^{\circ}$ and direction II (B) with a declination of $34^{\circ}$ and inclination of $9^{\circ}$ (Fig. 2). The magnetic polarity scale of the sampled part of the section is the following: depth intervals from the bottom to $3.13 \mathrm{~m}$ and from 2.60 to $1.0 \mathrm{~m}$ represent normal magnetic polarity, while the depth interval from 2.60 to 3.13 m represents reversed polarity. The latter could be linked to the Blake geomagnetic inversion (Fig. 2 and Appendix 1: table 1*).

A series of thermoluminescent dates from the deposits of the Zaslavl section was obtained by L.T. Voskovskaya at Moscow State University according to the method developed by A.I. Shlyukov (Sanko et al., 2017). The absolute age of the lake sediments deposited during the transition from the Pripiatian (Saalian) Late Glacial to the Muravian (Eemian) Interglacial turned out to be $128,000 \pm 11,000$ (TLM-429). Five more thermoluminescence dates obtained from the deposits (between the peat and loess units) indicate an Early Poozerian (Weichselian) depositional age. At the same time, it should be noted that there is no regular pattern in the distribution of thermoluminescence dates - the lowermost sample (TLM-430) has a date of 70,000 $\pm 5,000$ years, while the overlying sample yielded an older age of $130,000 \pm 10,000$ years (TLM-433), while a similar juxtaposition of younger and older dates was observed in the remaining part of the section (Sanko et al., 2017).

2. Zhukevichi section. AMS measurements of 44 oriented samples from the Zhukevichi section show two directions of sedimentary material orientation. All samples have a general di- rection of $14^{\circ}$ with a $5^{\circ}$ dip angle. Direction I is $8^{\circ}$ with a low dip angle. The second direction (II) azimuth (i.e. from west to east) is $86^{\circ}$ with a low dip angle. Direction II was detected only in the lower part of the section (Fig. 3 and Appendix 1: table 2).

The magnetic polarity record in the Zhukevichi section shows normal magnetic polarity from the bottom to the top. The Blake geomagnetic excursion was not identified in this section.

3. Ponemun section. The results of AMS measurement of 42 oriented samples from the Ponemun section show two directions of the flow of sedimentary material. The data of two samples was not reliable and was removed from the statistical analysis. All samples have a sedimentary flow direction of $55^{\circ}$ with a $1^{\circ}$ dip angle. Direction I - all samples have the general direction of $50^{\circ}$ with a low dip angle. Direction II - an azimuth direction of $140^{\circ}$ (from the northwest to the southeast) with a low dip angle. Direction II was detected only in the middle part of the section (Fig. 4 and Appendix 1: table 3).

The Ponemun section showed normal polarity from the bottom to top of the segment sampled; the Blake geomagnetic excursion was not identified.

4. Netiesos section. More detailed palaeomagnetic investigations were performed on that part of the Netiesos section where the Blake excursion had previously been detected (Baltrūnas et al., 2013). The Blake Event was constrained by 18 samples in a $38 \mathrm{~cm}$ thickness interval (Fig. 5 and Appendix 1: table 4)

The present study reveals that the Blake Event in the Netiesos section resolves into 5 intervals of different polarity: 3 of reversed polarity and 2 of normal polarity. The highest compatibility of isochron-calibrated dates for the Netiesos section calculated using the L/L and TSD techniques was determined for a combination of three samples. With the help of the correction index $f$ (intercept of isochrons on the ordinates axis in the plot of ${ }^{230} \mathrm{Th} /{ }^{232} \mathrm{Th}$ vs. ${ }^{234} \mathrm{U} /{ }^{232} \mathrm{Th}$ activity ratios), the contribution of the primary contamination with thorium was determined (Baltrūnas et.al., 2015). Applying the corrected analytical data, the isochron-calibrated ages were calculated: 108.8 $\pm 12.0 / 9.9 \mathrm{ka}$ for the $\mathrm{L} / \mathrm{L}$ technique and 100.2 $\pm 10.3 / 8.6 \mathrm{ka}$ for the TSD technique (Baltrūnas et al., 2015).

\section{DISCUSSION}

Reversals and excursions of the Earth's geomagnetic field are common. During the Quaternary Period, 27 well-documented geomagnetic field instabilities have been identified as short-lived excursions, 14 of those occurred during the Matuyama Chron and 13 during the Brunhes Chron. During the Quaternary Period, they occur nearly three times as often as full polarity reversals (Singer, 2014). However, geomagnetic excursions are much more difficult to detect and evaluate than are the polarity boundaries themselves. Magnetization directions during an excursion may record a complete polarity reversal, but more often they do not. Such excursions can be used as time markers if they can be uniquely identified, but high-resolution records of these phenomena are quite scarce, as they are short-lived and difficult to detect.

The Geomagnetic Instability Time Scale (GITS) is based on the direct dating of transitional polarity states in lava flows using the ${ }^{40} \mathrm{Ar} /{ }^{39} \mathrm{Ar}$ method, in parallel with astrochronological age models of marine deposits from which oxygen isotope and magnetic records have been obtained (Singer, 2014). The geomagnetic investigations of Singer et al. (2014) have shown that 


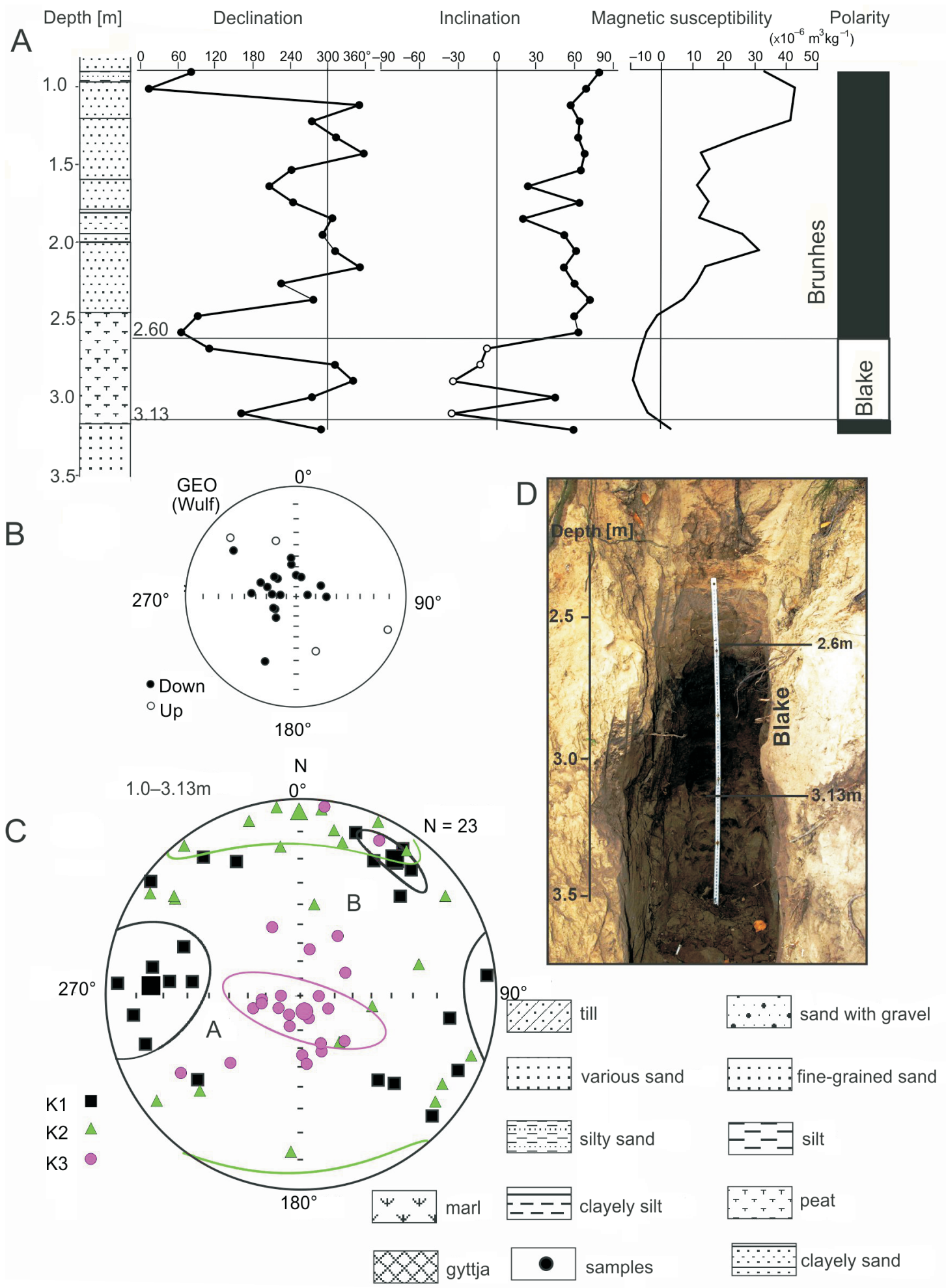

Fig. 2. Results of the palaeomagnetic investigations of the Zaslavl section

A - lithology and data of palaeomagnetic characteristics; B - characteristic remanence (ChRM) directions; C - directional results of the anisotropy of magnetic susceptibility (AMS) of the sections investigated; small symbols represent specimen eigenvectors, large symbols represent mean eigenvectors: $\mathrm{K} 1=\mathrm{K}_{\max }$ (long axis), $\mathrm{K} 2=\mathrm{K}_{\text {int }}$ (integer axis), $\mathrm{K} 3=\mathrm{K}_{\min }$ (short axis) (Appendix 1: table 1); $\mathbf{D}-$ part of the Zaslavl section within which the Blake subchron was recorded 

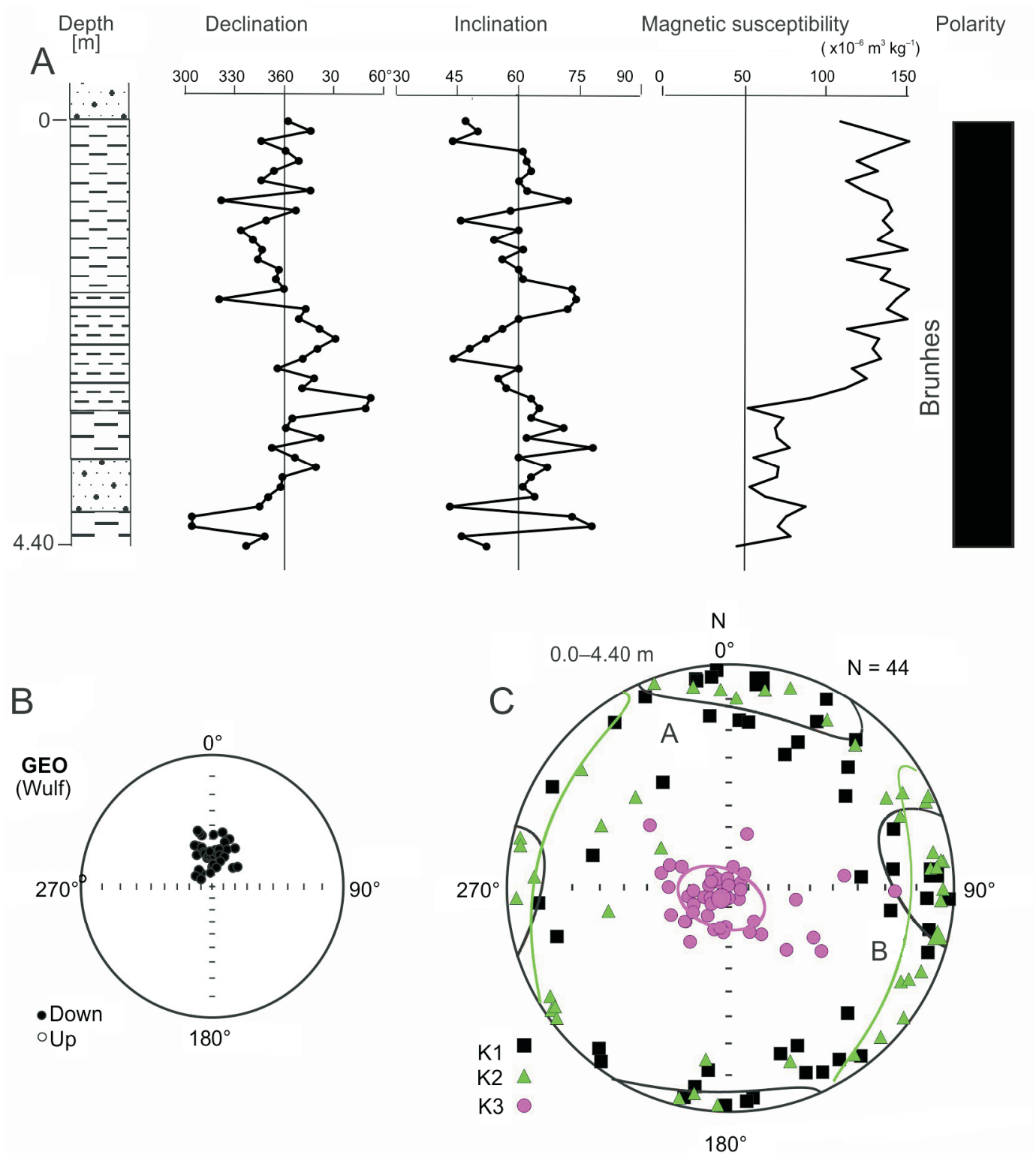

Fig. 3. Results of the palaeomagnetic investigations of the Zhukevichi section

A - lithology and data of palaeomagnetic characteristics; B - characteristic remanence (ChRM) directions; C directional results of the anisotropy of magnetic susceptibility (AMS) of the sections investigated; small symbols represent specimen eigenvectors, large symbols represent mean eigenvectors: $\mathrm{K}_{1}=\mathrm{K}_{\max }$ (long axis), $\mathrm{K} 2=\mathrm{K}_{\text {int }}$ (integer axis), $\mathrm{K} 3=\mathrm{K}_{\min }$ (short axis) (Appendix 1: table 2); other explanations as in Figure 2

five ${ }^{40} \mathrm{Ar} /{ }^{39} \mathrm{Ar}$ incremental heating experiments on the Amsterdam Island lava yield a plateau age of $120 \pm 12 \mathrm{ka}$, whereas ages from two sites in the Calderon flow, New Mexico, are $112 \pm 23$ and $101 \pm 14 \mathrm{ka}$, together giving a weighted mean of $104 \pm 12 \mathrm{ka}$. The age of $120 \pm 12 \mathrm{ka}$ from Amsterdam Island, though imprecise, correlates with the Blake excursion. By contrast, the 104-105 ka age obtained from both Lipari Island and the Calderon flow, New Mexico, indicates that these lavas record a younger period of dynamo instability, most probably associated with the post-Blake excursion. These radiometric ages are consistent with the astronomical ages of two palaeointensity minima in the PISO-1500 global stack. These findings indicate that the Blake and post-Blake excursions are both global features of the past geodynamo behaviour (Singer et al., 2014).

Sier et al. (2015) summarized numerous independent age estimates for the Blake Event available from a number of stud- ies and point out that they generally indicate a younger age than that of sapropel S5. In a stalagmite in northern Spain the Blake Event is U/Th-dated and spans the interval from $119.3 \pm 0.8$ to $112.0 \pm 1.9 \mathrm{ka}$ (including their B3 part of the event) and postdates the isotope signal peak correlated to MIS $5 \mathrm{e}$ (Osete et al., 2012; Sier et al., 2015).

Our previous study of the Netiesos site in southern Lithuania (Baltrūnas et al., 2013) reveals that the dating of the base of the Blake Event obtained from the ESR dating of freshwater molluscs is $112.5 \pm 10.8$ and $112.1 \pm 25.9$ ka (Gaigalas and Molodkov, 2002), whereas the top of the sequence produced $\mathrm{U} / \mathrm{Th}$ dates of $108.8 \pm 8.7$ and $105.7 \pm 10.0 \mathrm{ka}$ (Gaigalas et al., 2005). The ${ }^{230} \mathrm{Th} / \mathrm{U}$ dates obtained in our present study (108.8 $\pm 12.0 / 9.9 \mathrm{ka}$ for the $\mathrm{L} / \mathrm{L}$ technique and $100.2 \pm 10.3 / 8.6 \mathrm{ka}$ for the TSD technique) emphasize that. 


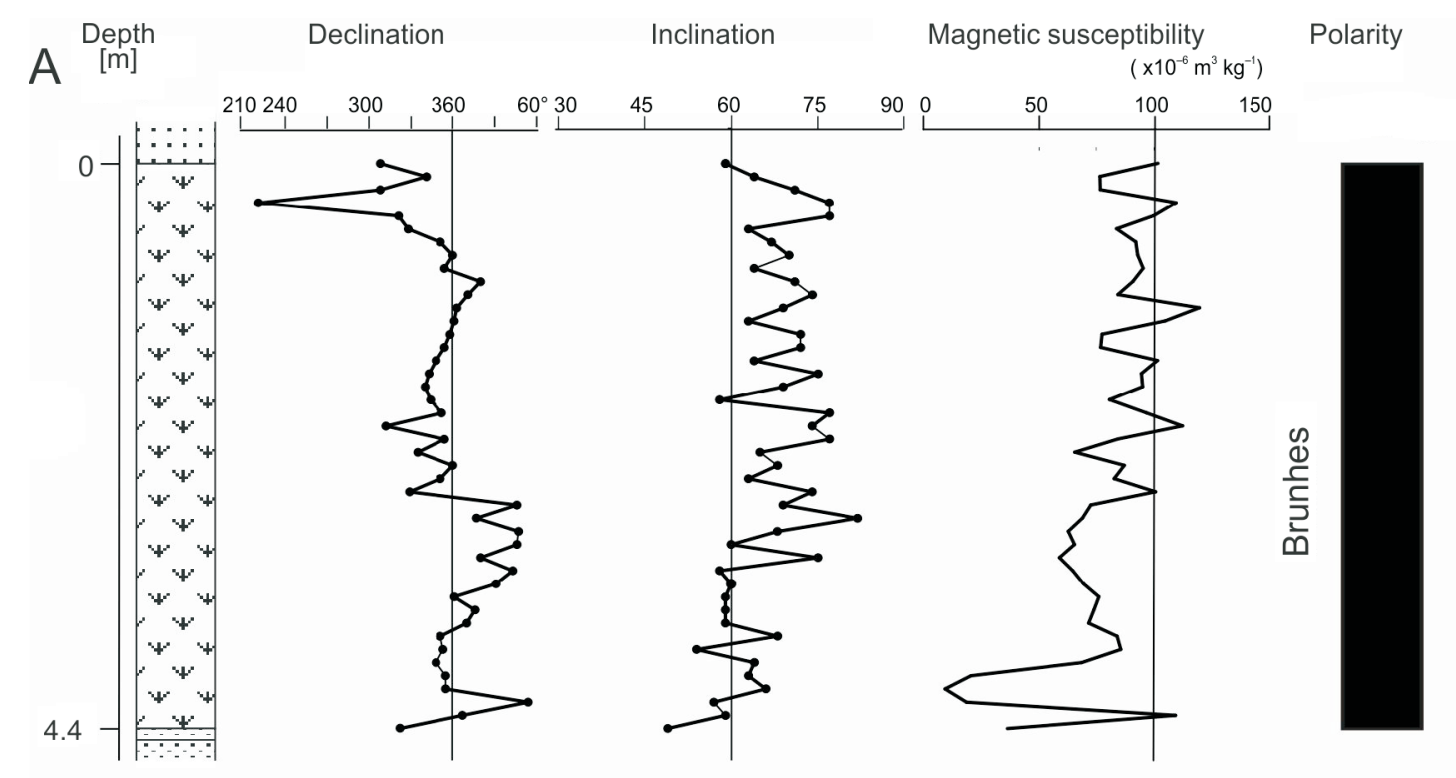

$\mathrm{B}$

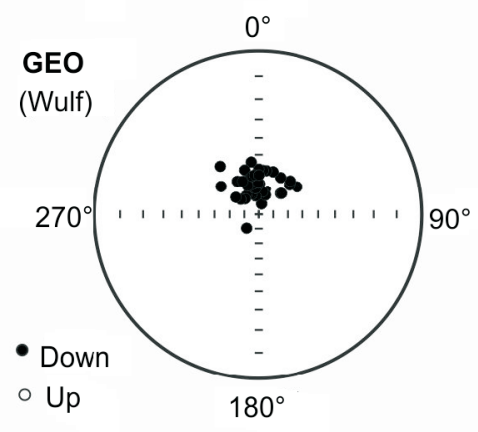

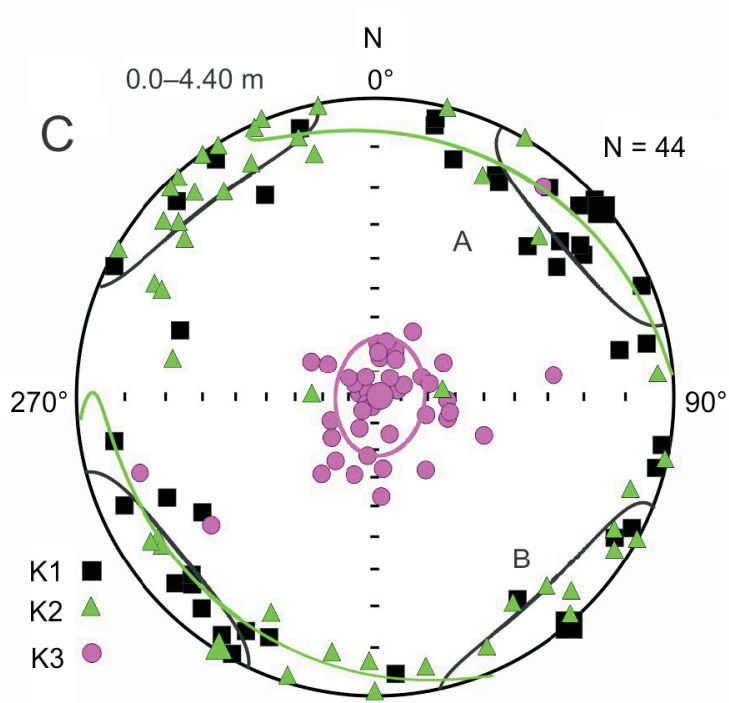

$180^{\circ}$

Fig. 4. Results of palaeomagnetic investigations of the Ponemun section

A - lithology and data of palaeomagnetic characteristics; B - characteristic remanence (ChRM) directions; C - directional results of the anisotropy of magnetic susceptibility (AMS) of the sections investigated; small symbols represent specimen eigenvectors, large symbols represent mean eigenvectors: $\mathrm{K} 1=\mathrm{K}_{\max }$ (long axis), $\mathrm{K} 2=\mathrm{K}_{\text {int }}$ (integer axis), $\mathrm{K} 3=\mathrm{K}_{\min }$ (short axis) (Appendix 1: table 3); other explanations as in Figure 2

The Caours tufa-sequence, northern France, produced a set of U/Th (TIMS) dates of 120 ka (Antoine et al., 2006) that relate to the base of the Blake Event $(123 \pm 3 \mathrm{ka}$; Sier et al., 2015). In the Rutten core, the Netherlands, luminescence dates of $109 \pm 6$ and $112 \pm 11 \mathrm{ka}$ are from within the Blake Event (Sier et al., 2015). The identification of the Blake Event at these two sites and correlation to findings in the marine core indicate that NW and central Europe entered interglacial environmental conditions 5000 years later than southern Europe (Sier et al., 2015).

The present study reveals that the Blake Event in the Netiesos section consisting of three short reversed polarity intervals separated by two short normal polarity intervals (Fig. 5). The directional changes are clear. The change of the polarity in the Blake Event is recorded in other regions (e.g., Fang et al., 1997; Osete et al., 2012; Sier et al., 2013; Govin et al., 2015). However, there are records of another post-Blake excursion age of 104-105 ka (Singer et al., 2014; Govin et al., 2015). It is possible that in the Netiesos section these two (Blake and post-Blake) palaeomagnetic excursions are close to each other due to the small thickness of deposits.

As can be seen from the evidence described, the palaeomagnetic Blake Event is registered in the Netiesos and Snaigupèle sections in Lithuania and in the Zaslavl section in Belarus. In the Netiesos section, it (Blake) occurred during the Merkinè (Eemian) Interglacial $M_{3 a}$ (Quercus-Ulmus) pollen zone, which is consistent with the beginning of the climatic optimum of the interglacial phase. During that time, oak and elm forests spread in the area. In the Zaslavl section, the Blake Event is set in the lower part of the section, in the Zsl-1 local pollen zone (Carpinus-Tillia), which is correlated with the Murava (Eemian) Interglacial regional Mr-6 pollen zone (Karabanov and Yelovicheva, 1997; Karabanov et al., 2017). This is the second part of the climatic optimum reflecting the widespread occur- 

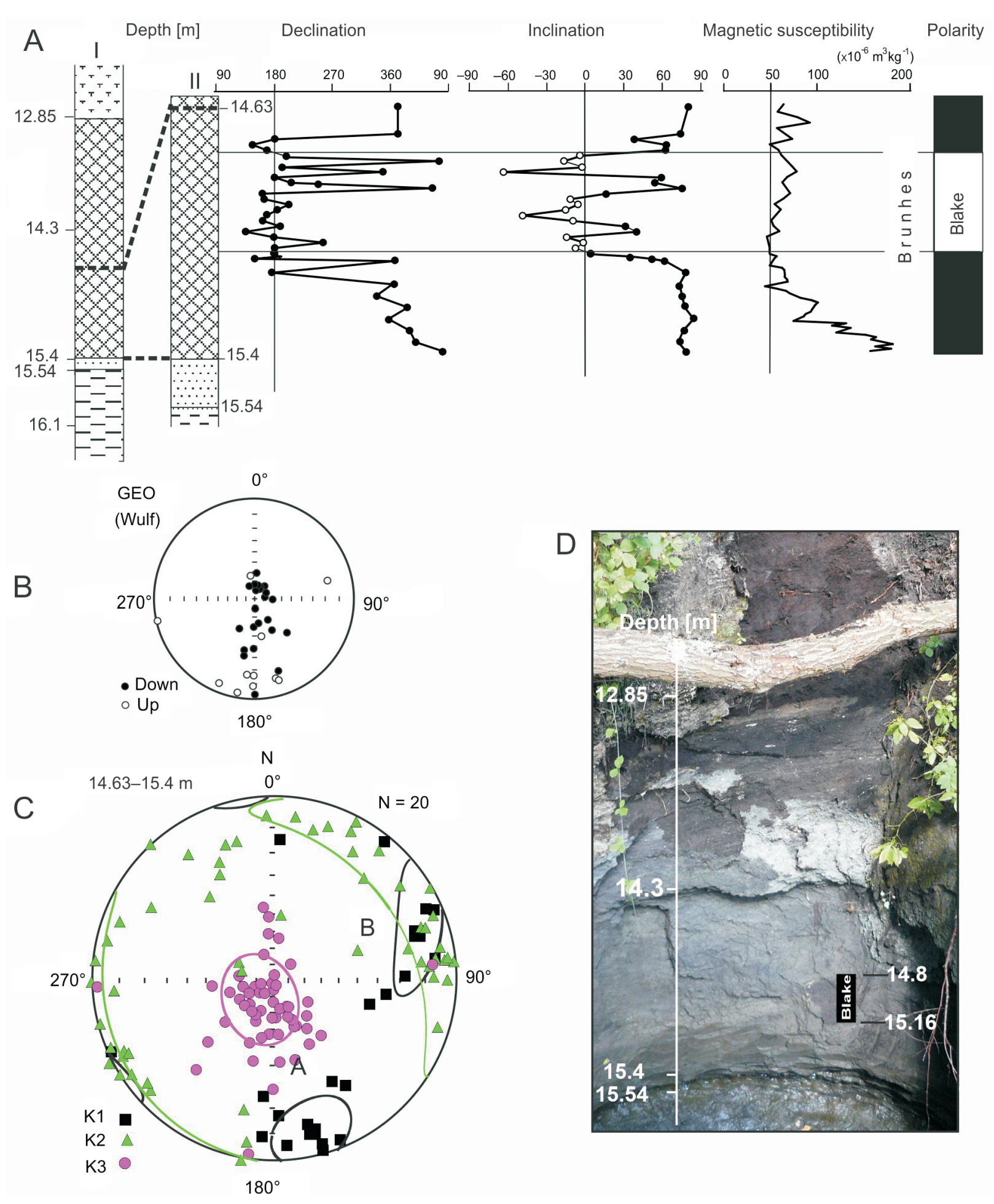

Fig. 5. Results of the palaeomagnetic investigations of the Netiesos section

A - lithology and data of the palaeomagnetic characteristics: I - previously investigated section, II - newly investigated fragment of the section; B - characteristic remanence (ChRM) directions; C - directional results of the anisotropy of magnetic susceptibility (AMS) of the sections investigated; small symbols represent specimen eigenvectors, large symbols represent mean eigenvectors: $\mathrm{K} 1=\mathrm{K}_{\max }$ (long axis), $\mathrm{K} 2=$ $\mathrm{K}_{\text {int }}$ (integer axis), $\mathrm{K} 3=\mathrm{K}_{\min }$ (short axis) (Appendix 1: table 4); D - part of the Netiesos section within which the Blake subchron was recorded; other explanations as in Figure 2 
rence of deciduous hornbeam-lime forests with hazel underbrush and abundant alder forests. In the Snaigupèle section, the Blake Event is linked to the second part of climatic optimum of the interglacial Corylus-Carpinus-Ulmus pollen zone (Baltrūnas et al., 2015). Despite the similarity of the pollen succession of Lithuania and Belarus, their comparison also revealed regional differences (Rylova et al., 2020). At the beginning of the interglacial, Siberian spruce (Picea obovata Ledeb.) was significantly less common in the forests of Belarus than in Lithuania; meanwhile, elm (Ulmus), oak (Quercus.) and European ash (Fraxinus excelsior L.) were present in Belarus forests, which at that time did not yet grow in Lithuania. Later, during the climatic optimum, such thermophilous trees as linden (Tilia) and hornbeam (Carpinus) were more widespread in Belarus forests, meanwhile the spruce (Picea) was more numerous in Lithuania. At the end of the interglacial, larch (Larix) spread in Belarus, while in Lithuania it was absent.

The Blake geomagnetic excursion was not identified in the Zhukevichi and Ponemun sections. In the Zhukevichi section, this was possibly caused by a hiatus in the section, as according to previous investigations $30 \%$ of the succession is free of pollen (Sanko et al., 2002). Therefore, the Blake Event may not be recorded by sediment. In the Ponemun section, determination of the absolute age of the sequence showed the end of the interglacial phase $(70 / 80-110$ thousand years), which indicates a younger age than the Blake Event (Yelovicheva, Zubovich, 2007), and so it was not fixed there. However, it cannot be ruled out that the Blake Event may have not been recorded in these sections for other reasons, such as post-depositional remagnetization, lock-in depth, dating bias, etc.

Sier et al. (2015) noted that the Characteristic Remanent Magnetization (ChRM) directions with southern declination and positive inclination reported in the Netiesos section (Baltrūnas et al., 2013) should also be interpreted as excursional following the definitions of Merril and McFadden (1994). Thus, it seems that the Blake Event of the Netiesos section in NE Europe spans the entire Eemian, similar to the new results for the Eemian in NW Europe and those for central Europe (Sier et al., 2015). Unfortunately, the deposits of the very end of the interglacial are missing in the Netiesos section according to palaeobotanical data (Kondratienè, 1996), and the lithology of the section (peat accumulation) suggests a break in sedimentation. Data from the Snaigupèle section (Baltrūnas et al., 2015) support the suggestion that the sediments of the Blake Event accumulated during the climatic optimum. However, dating of the organic deposits of the Snaigupèle section by the ${ }^{230} \mathrm{Th} / \mathrm{U}$ method yielded an age of $127 \pm 18 / 14$ ka for the $L / L$ technique ( $\Lambda$ YY-833L/L) and $132 \pm 22 / 16 \mathrm{ka}$ for the TSD technique ( $\Lambda$ YY-833TSD), which is older than that of the Netiesos section. Therefore, additional investigations are needed to properly determine the age of the base and the top of the Blake Event in the Snaigupele section. Meanwhile, in the Zaslavl section, the Blake Event covers the second part of climatic optimum, but the lowermost part of the interglacial is missing in the section and a series of thermoluminescent dates obtained by Sanko et al. (2017) are questionable, fluctuating between older and younger dates.

Correlation between the sections reveals varying completeness of their interglacial intervals, as well as problems in correlating local pollen zones with regional pollen zones, especially with the Eemian Interglacial pollen zones established in Western Europe. Therefore, it would be beneficial to re-examine the methodology of correlation of palaeogeographical histories for central and northern Europe. Correlation between the terrestrial records and ocean sequences shows that Eemian forests flourished up to MIS $5 \mathrm{~d}$ in south-western Europe, while a much shorter duration of Eemian Interglacial conditions in northwestern Europe is inferred (Kukla et al., 2002).

According to Helmens (2014), MIS 5 is characterized by three long forested intervals (broadly corresponding to MIS $5 \mathrm{e}$, $5 c, 5 a)$ both in temperate and northern boreal Europe. These mild periods were interrupted by two short, relatively cold and dry intervals (MIS $5 \mathrm{~d}$ and $5 \mathrm{~b}$ ) caused by the glaciation in Fennoscandia. The division between the Eemian (MIS 5e) and the Early Weichselian (MIS $5 d-a$ ) is not useful, as it is not relevant from a climate point of view (Helmens, 2014). This presumption is consistent with our data from the Netiesos section (Baltrūnas et al., 2013) indicating the relatively warm character of stage $5 d$ and no glacigenic deposition up to stage 4. Relatively high temperatures were recorded for the Early Weichselian period in the Medininkai section in Lithuania (Seiriene et al., 2014) and northern Fennoscandia (Valiranta et al., 2009). Similarly, investigations in Northern Eurasia and the Voka section of the Gulf of Finland suggest that interglacial climatic conditions may have persisted until the end of MIS $5 \mathrm{a}$ (Molodkov and Bolikhovskaya, 2010, 2011).

\section{CONCLUSIONS}

Preliminary palaeomagnetic investigations of five Eemian (Murava, Merkine) Interglacial sections have demonstrated a consistent detection of the Brunhes normal magnetic field with a short-term reversal - the Blake Event - recorded in three sections: Netiesos, Snaigupèlè, and Zaslavl.

The Blake Event in the Netiesos section is characterized by a three short reversed polarity intervals separated by two short normal polarity intervals. ESR dating $(112.5 \pm 10.8 \mathrm{ka}$ and 112.1 $\pm 25.9 \mathrm{ka}$ ) and ${ }^{230} \mathrm{Th} / \mathrm{U}$ dates obtained from this section (108.8 $\pm 12.0 / 9.9 \mathrm{ka}$ for the L/L technique and 100.2 $\pm 10.3 / 8.6 \mathrm{ka}$ for the TSD technique) suggest that two (Blake and post-Blake) palaeomagnetic excursions may be present in this section, in close proximity due to a slow ssedimentation rate.

The absence of the Blake Event in the remaining two sections was possibly caused by incompleteness of the interglacial sections studied and a very small stratigraphic thickness $(\sim 36-50 \mathrm{~cm})$ formed during this reversal.

The complexity of interregional correlation of pollen zones of the Eemian Interglacial sections studied and the radiogenic age dates of the palaeomagnetic Blake Event obtained from some sections suggest that the Blake Event took place during the climatic optimum of Eemian Interglacial. Further palaeomagnetic research and precise dating results are needed for more precise determination of its duration.

Our research supports the inference of a different onset and duration of the last interglacial in Western and Eastern Europe. The evidence suggests a much shorter duration of Eemian conditions in Eastern Europe than in SW and W Europe, although the stages of forest development are similar.

Acknowledgements. We are grateful for the constructive comments by Laimdota Kalnina and an anonymous reviewer. The research was supported by the Research Council of Lithuania (TAP LB 10/2013) and Belarusian Republican Foundation for Fundamental Research (No. X19MC-021). The authors express sincere thanks to Dr. V. Kuznetsov and Dr. F. Maksimov (St. Petersburg State University) for results of ${ }^{230} \mathrm{Th} / \mathrm{U}$ dating of interglacial organic deposits in the Netiesos section. 


\section{REFERENCES}

Antoine, P., Limondin-Lozouet, N., Auguste, P., Locht, J.L., Ghaleb, B., Reyss, J.L., Escude, E., Carbonel, P., Mercier, N., Bahain, J.J., Falgueres, C., Voinchet, P., 2006. Le tuf de Caours (Somme, France): mise en évidence d'une séquence éemienne et d'un site paléolithique associé. Quaternaire, 17: 281-320.

Baltrūnas, V., Šeirienè, V., Molodkov, A., Zinkutè, R., Katinas, V., Karmaza, B., Kisielienè, D., Petrošius, R., Taraškevičius, R., Piličiauskas, G., Schmolcke, U., Heinrich, D., 2013. Depositional environment and climate changes during the late Pleistocene as recorded by the Netiesos section in southern Lithuania. Quaternary International, 292: 136-149.

Baltrūnas, V., Maksimov, F.E., Kuznetsov, V.Yu, Karmaza, B., Katinas, V., 2015. Geochronology and palaeomagnetic records of the Snaigupèle section in South Lithuania. Geochronometria, 42: $172-181$.

Bitinas, A., Katinas, V., Rudnickaitè, E., Šinkūnas, P., 2014. Vetygala Exposure: the problem of the lower boundary of the Pleistocene. Geologija, 56: 47-53.

Bitinas, A., Katinas, V., Gibbard, P.L., Saarmann, S., Damušytė, A., Rudnickaitè, E., Baltrūnas, V., Satkūnas, J., 2015. The problem of the lower boundary of the Pleistocene in Eastern Lithuania. Quaternary International, 386: 89-101.

Cañón-Tapia, E., 2004. Anisotropy of magnetic susceptibility of lava flows and dykes: a historical account. Geological Society Special Publications, 238: 205-225.

Fang. X.-M., Li J.-J., Van der Voo, R., Niocaill, C.M., Dai. X.-R., Kemp, R.A., Derbyshire, E., Cao, J.-X., Wang, J.-M., Wang, G., 1997. A record of the Blake Event during the last interglacial paleosol in the western Loess Plateau of China. Earth and Planetary Science Letters, 146: 73-82.

Ferre, E., Martýn-Hernandez, F., Teyssier, C., Jackson, M., 2004. Paramagnetic and ferromagnetic anisotropy of magnetic susceptibility in migmatites: measurements in high and low fields and kinematic implications. Geophysical Journal International, 157: 1119-1129.

Gaigalas, A., Molodkov, A., 2002. ESR ages of three Lithuanian Mid-Late Pleistocene interglacials: methodical and stratigraphical approach. Geochronometria, 21: 57-64.

Gaigalas, A., Arslanov, Kh.A., Maksimov, F.E., Kuznetsov, V.Yu., Chernov, S.B., Melešytè, M., 2005. Results of uranium-thorium isochron dating of Netiesos section peat-bog in South Lithuania. Geologija, 51: 29-38.

Govin, A., Capron, E., Tzedakis, P.C., Verheyden, S., Ghaleb, B., Hillaire-Marcel, C., St-Onge, G., Stoner, J.S., Bassinot, F., Bazin, L., Blunier, T., Combourieu-Nebout, N., El Ouahabi, A., Genty, D., Gersonde, R., Jimenez-Amat, P., Landais, A., Martrat, B., Masson-Delmotte, V., Parrenin, F., Seidenkrantz, M-Z., Veres, D., Waelbroeck, C., Zahn, R., 2015. Sequence of events from the onset to the demise of the Last Interglacial: evaluating strengths and limitations of chronologies used in climatic archives. Quaternary Science Reviews, 129: 1-36.

Graham, J.W., 1966. Significance of magnetic anisotropy in Appalachian sedimentary rocks. Geophysical Monograph Series, 10: 627-648.

Guobytè, R., Satkūnas, J., 2011. Pleistocene glaciations in Lithuania. Developments in Quaternary Science, 15: 231-246.

Helmens, K.F., 2014. The Last Interglacial - glacial cycle (MIS 5-2) re-examined based on long proxy records from central and northern Europe. Quaternary Science Reviews, 86: 115-143.

Henry, B., 1973. Studies of microtectonics, anisotropy of magnetic susceptibility and paleomagnetism of the Permian Dome de Barrot (France): paleotectonics and paleosedimentological implications. Tectonophysics, 17: 61-72.

Hrouda, F., 1979. The strain interpretation of magnetic anisotropy in rocks of the Nizky Jesenik Mountains (Czechoslovakia). Sbornik Geologickych Ved, UG 16: 27-62.

Hrouda, F., 2002. The use of the anisotropy of magnetic remanence in the resolution of the anisotropy of magnetic susceptibility into its ferromagnetic and paramagnetic components. Tectonophysics, 347: 269-281.

Hrouda, F., Janak, F., 1976. The changes in shape of the magnetic susceptibility ellipsoid during progressive metamorphism and deformation. Tectonophysics, 34: 135-148.

Hrouda, F., Janak, F., Rejl, L., 1978. Magnetic anisotropy and ductile deformation of rocks in zones of progressive regional metamorphism. Gerlands Beitrage zur Geophysik, 87: 126-134.

Jelinek, V., 1977. The statistical theory of measuring anisotropy of magnetic susceptibility of rocks and its application. Geofyzika, Brno.

Jezek, J., Hrouda, F., 2004. Determination of the orientation of magnetic minerals from the anisotropy of magnetic susceptibility. Geological Society Special Publications, 238: 9-20.

Karabanov, A.K., Matveyev, A.V., 2011. The Pleistocene glaciations in Belarus. Developments in Quaternary Science, 15: 29-35.

Karabanov, A.K., Yelovicheva, Ya.K., 1997. Geological objects of excursions. "Zaslavl" Quarry. In: Excursions guide book of INQUA Commission on Glaciation the Peribaltic group "Quaternary deposits and neotectonics in the area of Pleistocene glaciations" May 12-16, 1997, Minsk (ed. A. Matveev): 15-18. Institute of Geological Sciences, Minsk.

Karabanov, A.K., Baltrūnas, V., Bogdasarov, M.A., Gaidukevich, O.M., Zernitskaya, V.P., Karmaza, B., Katinas, V., Kisielienè, D., Kurzo, B.V., Rylova, T.B., Savchenko, I.E., Stančikaitè, M., Šeirienè, V., Šinkūnas, P., Šinkūnè, E., 2017. Osnovniye rezultaty sovmestnykh belorussko-litovskikh issledovaniy $\mathrm{V}$ oblasti nauk o Zemle (in Russian). In: Aktualniye problemi nauk o Zemle: ispolzovaniye prirodnykh resursov i sokhraneniye okruzhayushchey sredy. Sbornik materialov Mezhdunar. nauch. - prakt. konf., posvyashch. godu nauki v resp. Belarus (eds. A.K. Karabanov and M.A. Bogdasarov), 2: 273-280. Brest State A.S. Pushkin University, Brest.

Kirschvink, J., 1980. The least squares line and plane and the analysis of paleomagnetic data. Geophysical Journal of the Royal Astronomical Society, 62: 699-718.

Kondratiene, O., 1996. The Quaternary stratigraphy and palaeogeography of Lithuania based on paleobotanic studies (in Russian with English summary). Academia, Vilnius.

Kukla, G.J., Bender, M.L., de Beaulieu, J.L., Bond, G., Broecker, W.S., Cleveringa, P., Gavin, J.E., Herbert, T.D., Imbrie, J., Jouzel, J., Keigwin, L.D., Knudsen, K.-L., McManus, J.F., Merkt, J., Muhs, D.R., Müller, H., Poore, R.Z., Porter, S.C., Seret, G., Shackleton, N.J., Turner, C., Tzedakis, P.C., Winograd, I.J., 2002. Last interglacial climates. Quaternary Research, 58: 2-13.

Kuznetsov, V., Maksimov, F., 2012. Metody chetvertichnoy geokhronometrii v paleogeografii i morskoy geologii (in Russian). St. Petersburg, Nauka.

Lindner, L., Sanko, A., 2008. Late Pleistocene evolution of the Niemen River valley near Grodno in Belarus (in Polish with English summary). Przegląd Geologiczny, 56: 73-80.

Maksimov, F.E., Kuznetsov, V.Yu., 2010. New version of the ${ }^{230} \mathrm{Th} / \mathrm{U}$ dating of the Upper and Middle Pleistocene buried organic-rich sediments. Bulletin of St. Petersburg State University, 7: 103-114.

Merrill, R.T., McFadden, P.L., 1994. Geomagnetic field stability: reversal events and excursions. Earth and Planetary Science Letters, 121: 57-69.

Osete, M.-A., Martin-Chivelet, J., Rossi, C., Edwards, R.L., Egji, R., Munoz-Garcia, M.B., Wang, X., Pavon-Carrasco, J., Heller, F., 2012. The Blake geomagnetic excursion recorded in a radiometrically dated speleothem. Earth and Planetary Science Letters, 353-354: 173-181.

Pevzner, M., Gaigalas, A., 1976. Ostatochnaya namagnichennost (in Russian). In: Pogrebenniye paleovrezi poverkhnosti dochvertichnikh porod yuzhnoy Pribaltiki (ed. A. Gaigalas): 65-75. Mokslas, Vilnius. 
Rylova, T.B., Demidova, S.V., Shidlovskaya, A.V., 2020.Stratigraphy of the Muravian sediments of the northwestern Belarus and paleogeographic reconstructions according to paleobotanical data (in Russian with English summary). Litasfera, 2: 50-68.

Sanko, A.F., Moiseev, E.I., 1996. Piervoye opredeleniye paleomagnitnoy granitsy Brunhes-Matuyama $v$ pleistotsenovykh otlozheniyakh Belarusii (in Russian). Reports of Academy of Sciences of Belarus, 50: 106-109.

Sanko, A., Anoshko, M., Rylova, T., Savchenko, I., Velichkevich, F., Astapova, S., Motuzko, A., Badiay, V., 2002. Upper Dniepr (Saalian) and Muravian (Eemian) sequence at Zhukevichi. In: Field Symposium on Quaternary Geology and Geodynamics in Belarus. The Peribaltic group of INQUA Commission on Glaciation, Belarussian National Committee of INQUA, May 20-25th 2002, Grodno. Excursion Guide (ed. I. Pavlovskaya): 20-27. Institute of Geological Sciences, Minsk.

Sanko, A.F., Velichkevich, F.Yu., Moiseyev, E.I., Rylova, T.B., Savchenko, I.E., Kruchek, S.A., 2004. The Obukhovo outcrop as a parastratotype of the Belovezhian Interglacial of Belarus (in Belarusian with English summary). Lithosphere (Litasfera), 2: 38-51.

Sanko, A.F., Karabanov, A.K., Yelovicheva, Ya.K., Litviniuk, G.I., 2017. Razrez Zaslavl (in Russian). In: Sovremenniye problemi geokhimiyi, geologiyi i poiskov mestorozhdeniy poleznykh iskopaemykh. Materialy mezhdunarodnoiy nauchnoiy konferentsiyi, 23-25 maya 2017 (ed. O.V. Lukashov): 143-148. Pravo I ekonomika, Minsk.

Sier, M.J., Dekkers, M.J., 2013. Magnetic property analysis as palaeoenvironmental proxy: a case study of the Last Interglacial Middle Palaeolithic site at Neumark-Nord 2 (Germany). Eröffentlichungen des Landesamtes für Denkmalpflege und Archäeologie, 69: 117-130.
Sier, M.J., Parés, J.M., Antoine, P., Locht, J.-L., Dekkers, M.J., Limondin-Lozouet, N., Roebroeks, W., 2015. Evidence for the Blake Event recorded at the Eemian archaeological site of Caours, France. Quaternary International, 357: 149-157.

Singer, B.S., 2014. A Quaternary geomagnetic instability time scale. Quaternary Geochronology, 21: 29-52.

Singer, B.S., Guillou, H., Jicha, B.R., Zanella, E., Camps, P., 2014. Refining the Quaternary geomagnetic instability time scale (GITS): lava flow recordings of the Blake and Post-Blake excursions. Quaternary Geochronology, 21: 16-28.

Šeirienė, V., Kühl, N., Kisielienè, D., 2014. Quantitative reconstruction of climate variability during the Eemian (Merkinè) and Weichselian (Nemunas) in Lithuania, Quaternary Research, 82: 229-235.

Seeirienè, V., Karabanov, A., Rylova, T., Baltrūnas, V., Savchenko, I., 2015. The Pleistocene stratigraphy of the south-eastern sector of the Scandinavian glaciation (Belarus and Lithuania): a review. Baltica, 28: 51-60.

Tarling, D.H., Hrouda, F., 1993. The Magnetic Anisotropy of Rocks. London, Chapman \& Hall.

Valiranta, M., Birks, H.H., Helmens, K., Engels, S., Piirainen, M., 2009. Early Weichselian interstadial (MIS 5c) summer temperatures were higher than today in northern Fennoscandia. Quaternary Science Reviews, 28: 777-782.

Yelovicheva, Ya., Zubovich, S., 2007. Features of the palaeogeographical development of the terrains of Belarus and Ukraine in Pleistocene (in Russian with English summary). Osobennosti paleogeografichesk ogorazvitiya territorii Belarusi i Ukraini $v$ Pleistocene. Problemi srednepleistotsennogo interglatsiala: Materiali XIV ukrainskogo-polskogo seminara, Luck, 12-16 veresnia, 2007: 129-162, Lvov. 